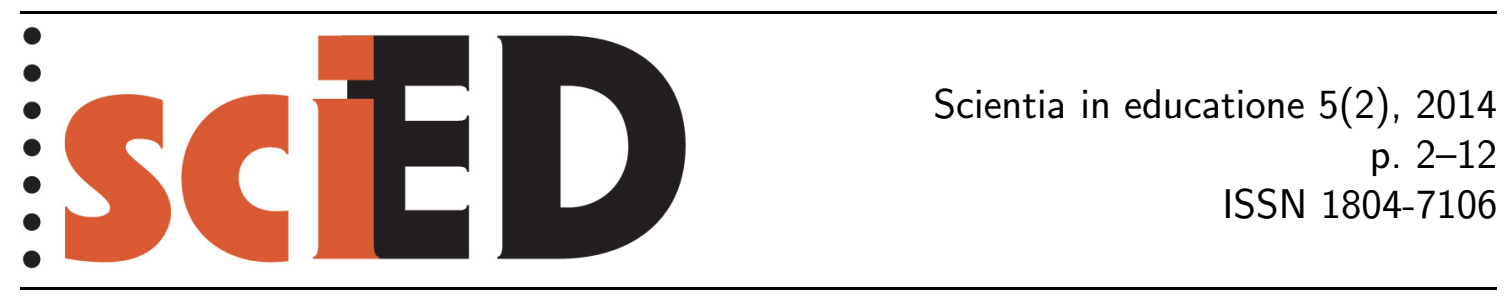

\title{
Role multimédií ve výuce přírodních věd
}

\author{
Tereza Odcházelová
}

\begin{abstract}
Abstrakt
V posledních letech je zaznamenáván celoevropský trend poklesu zájmu o studium př́írodních věd. Tento fakt logicky vede didaktiky a učitele přírodovědných oborů $\mathrm{k}$ hledání nových efektivnějších a pro žáky přitažlivějších vzdělávacích metod a př́istupů k výuce. Cílem této studie je představit multimédia jako vhodný prvek pro realizaci výuky v souladu $\mathrm{s}$ doporučovanými didaktickými metodami a přístupy $\mathrm{k}$ př́rodovědnému vzdělávání. Moderní výukové prostředky a informační technologie umožňují nejen zatraktivnění výuky, zvýšení motivace žáků $\mathrm{k}$ učení a aktivní zapojení žáků do výuky, ale jsou také vhodným nástrojem pro propojení teorie a současné praxe.
\end{abstract}

Klíčová slova: multimédia, přírodní vědy, výukové trendy, motivace.

\section{The Role of Multimedia in Science Education}

\begin{abstract}
Recently, there has been a significant decline in interest in natural science among all European countries. This fact clearly leads scientists in didactics and teachers of natural sciences to searching for new, more effective and more attractive learning methods and teaching approaches. The main aim of this study is to present multimedia as a suitable tool for teaching science in accordance with mostly recommended didactic methods. These "new" resources and technology make the education of natural science more attractive, increase learning motivation of the pupils, actively involve the pupils and it is an ideal mediator for linking theory and practice in educational process.
\end{abstract}

Key words: multimedia, natural sciences, trends in education, motivation. 


\section{Historické A SOUČASNÉ TRENDY PŘÍRODOVĚDNÉHO VZDĚLÁVÁNÍ}

Přírodovědné vzdělávání prodělalo od počátku 20. století nejen četné etapy rozvoje, ale také období charakterizovaná útlumem a poklesem zájmu o přírodní vědy (např. Škoda \& Doulík, 2009). Jednotlivé etapy se různou měrou podílely na formování dnešní podoby přrírodovědného vzdělávání, nicméně je jednoznačné, že hlavní myšlenky a záměry se vesměs shodují s těmi, které již byly aplikovány v uplynulých desetiletích. Jejich společným znakem vždy byla a stále je snaha najít ideální podobu vzdělávání, která by zaručovala maximální efektivitu a atraktivitu výuky př́rodovědných oborů. S tím také souvisí nepřetržité hledání nových efektivních a atraktivních výukových metod, strategií a výukových prostředků, které by přírodovědné vzdělávání oživily, zpopularizovaly a zvrátily nebo alespoň zmírnily současný celoevropský trend nezájmu žáků a studentů o př́rodní vědy (viz např. White Wolf Consulting, 2009; Víšek \& Kleskeň, 2010).

Výuce přírodních věd je nejčastěji vyčítáno přílišné teoretizování, přehnané požadavky na množství vzdělávacího obsahu a malá propojenost výuky s praktickým životem (White Wolf Constulting, 2009: s. 26-52). Aplikace tradičních vzdělávacích přístupů a jejich kritika má za následek určitý kompromis mezi samotným vzděláváním žáků a uspokojováním potřeb soudobé společnosti. V souladu s požadavky různých institucí v soukromém i státním sektoru se školství začíná orientovat na „produkci“ žáků, kteří jsou kreativní, umí kriticky a analyticky myslet a jsou schopni samostatně řešit různorodé problémy (Joshi, 2011). Př́mou reakcí na tyto požadavky je zavádění tzv. činnostního vyučování a hledání efektivních aktivizujících metod. V dnešní době bychom tyto metody charakterizovali jako proces, při němž žák aktivně, vědomě a uvědoměle třídí data, zařazuje je do poznatkových struktur, analyzuje, srovnává a hodnotí informace, učí se samostatnosti, tvořivosti a rozvíjí svoji osobnost. Primárním cílem činnostního vyučování je přeměna pasivních žáků (posluchačů) v účastníky výuky, kteří se přímou zkušeností naučí více než při jednostranném použití tradičních frontálních výukových metod (Kotrba \& Lacina, 2007). $\mathrm{V}$ dobách, kdy nebyly dostupné takové prostředky, jaké máme $\mathrm{k}$ dispozici dnes, Řehák mezi motivační a aktivizující vyučovací metody řadil (1967) např. i laboratorní práce, samostatné pozorování, ostatní práce vyžadující manuální činnost, ale také práci s odbornou literaturou. Podobně jako dnes kladli přední čeští didaktici hlavní důraz na utváření představ a pojmů založeném na smyslovém vnímání, přímém pozorování věcí a jevů a především na vlastní zkušenosti žáka (Komenský, 1958; Řehák, 1967; Altmann, 1975). U Altmanna se s touto myšlenkou setkáváme v rámci „didaktické zásady názornosti“ (1975: s. 209-217), Řehák podobnou myšlenku formuloval jako „zásadu uvědomělosti a aktivity žáků“ (1967: s. 97-99).

Dalším charakteristickým rysem soudobého přírodovědného vzdělávání, jak uvádí již zmíněná výzkumná zpráva White Wolf Consulting (2009: s. 26-52) je, že žáci sice považují přírodovědné předměty za zajímavé a pro další život užitečné, nicméně mají pocit, že jsou př́liš náročné a tím pádem nejsou tolik oblíbené. Děvčata zaujímají $\mathrm{k}$ přírodním vědám pozitivnější postoj a v př́rodopise mají lepší prospěch než chlapci (Pavelková et al., 2010). Výuku př́rodovědných předmětů považují žáci často za odtrženou od každodenní praxe a předpokládají, že základem zvládnutí daného učiva je vrozené logické myšlení (White Wolf Consulting, 2009: s. 26-52). Akcelerace nárůstu nových přírodovědných poznatků a možností jejich využití v různých oblastech praxe má za následek předimenzovanost vzdělávacího obsahu, která se bezpochyby neshoduje s požadavky společnosti na př́rodovědné či jiné vzdělá- 
vání (Veselský, 2010). Od přírodovědného vzdělávání se očekává spíše orientace na práci v moderní společnosti a adaptabilita do různých profesních odvětví. Jistou analogii vidíme u Altmanna a jeho didaktické zásady „spojení teorie s praxí“ (1975: s. 217-223) a zásady „uvědomělosti osvojených vědomosti““ (s. 226-228). Altmann (1975) hovoří o vytváření tzv. vědeckého světového názoru a osobního přesvědčení žáků s důrazem na kladný postoj $\mathrm{k}$ biologickému učivu a přeměnu vědomostí z biologie ve schopnost kriticky posuzovat problémy každodenní praxe (s. 228). Paralelu $\mathrm{k}$ jeho vědeckému světovému názoru nachází současné pojetí přírodovědného vzdělávání v pojmu přírodovědná gramotnost (VƯP, 2011). Vymezuje požadavky na rozvoj žákovy osobnosti, kterými jsou mimo jiné osobní utváření postojů k problematice přírodních věd, využívání přírodovědných znalostí v souvislosti s dalšími vzdělávacími oblastmi a jejich zasazení do kontextu každodenní praxe. Žák je formován prostřednictvím získávání tzv. klíčových kompetencí (RVP, 2007), kterých je dosahováno různými realizačními postupy.

Mezinárodní srovnávací studie PISA (The Programme for International Student Assessment) a TIMSS (The Trends in International Mathematics and Science Study), analyzující dovednosti a vědomosti žáků v zemích OECD, prokazují v letech 1995-2007 zhoršení přírodovědné gramotnosti českých i slovenských žáků (Santiago et al., 2012). Held (2011) zdůrazňuje značnou disproporci ve výsledcích zmíněných studií u českých a slovenských žáků především v oblasti úrovně znalosti obsahu učiva, tj. vědomostí, a žákovských dovedností, resp. schopnosti aplikace získaných poznatků do běžné praxe (přírodovědné zkoumání a uvažování). Podobně zpráva White Wolf Consulting (2009) uvádí, že v prokazování vědomostí dosahují v mezinárodním srovnávání čeští žáci relativně lepších výsledků a mají osvojeno velké množství přírodovědných poznatků, zatímco samostatné uvažování a zkoumání jim činí výrazně větší problémy. Schopnost používat vědecké poznatky, identifikovat otázky a na základě důkazů vyvozovat ověřené závěry je však př́imo obsažena ve vymezení oné přírodovědné gramotnosti (Veselský, 2010). Ceským žákům tyto schopnosti podle posledních výzkumů chybí (viz např. White Wolf Consulting, 2009; Santiago et al., 2012), což se logicky promítá do výsledků testování PISA nebo TIMSS, které jsou zaměřeny právě na tyto aspekty. Přirozenou reakcí českého přírodovědného vzdělávání by mělo být hledání vhodných řešení, která povedou ke zlepšení těchto výsledků a současně budou eliminovat rostoucí nezájem o přírodovědné předměty.

$\mathrm{Na}$ osobu učitele jsou v souvislosti s výše zmíněnými skutečnostmi kladeny poměrně vysoké nároky, které mimo jiné vyžadují, aby disponoval tzv. „didaktickou znalostí obsahu“ (Schulman, 1987). Jedná se o základní předpoklad ke zvládání učitelské profese umožňující učiteli práci s učivem. Musí při tom respektovat možnosti žáků a požadavky přírodovědných disciplín. Nejde o pouhé předání odborných znalostí, ale také o zprostředkování postojů, dovedností a hodnot s přesahem do dalších oblastí společnosti (např. umění, kultura, náboženství). Odbornost přírodních věd by měla zůstat zachována do takové míry, aby se daný obor nestal pro žáky nepřístupný a odrazující. Umění učitele je v rychlých reakcích, uvádění informací do širšího kontextu a ve volbě terminologie, kterou ve výuce použivá (Schulman, 1987). Úpravami obsahové stránky učiva a výukových forem spojených s ohledem na žáky a jejich individualitu, věk a stupeň rozumového vývoje, se zabývají již Altmann (1975: s. 223-226) a Rehák (1967: 110-112) a definují tzv. „didaktickou zásadu přiměřenosti“. V dnešní době zahrnuje didaktická znalost obsahu i takové prvky, jako je respektování rozvoje moderních technologií a jejich osvícené zavádění přímo do vyučovacího procesu. Jde do jisté míry o přizpůsobení se žákům, pro které jsou multimédia a informační technologie na denním pořádku. Použití multimédií však 
přináší učitelům také výhodu různými způsoby prezentovat informace s ohledem na úroveň a vzdělávací potřeby všech žáků ve třídě, což s pedagogickou znalostí obsahu úzce souvisí. Aplikace multimédií do výuky je navíc v souladu i s ostatními výše zmiňovanými požadavky na učitele př́rodních věd, jako jsou např. maximální názornost výuky, aktivní zapojení žáků do výuky a vhodná implementace multimédií do vyučovacích hodin se může státúčelným nástrojem pro celkový rozvoj žákovy osobnosti.

\section{VYMEZENÍ POJMU MULTIMÉDIA}

Abychom mohli plnohodnotně polemizovat o pozitivních a negativních stránkách implementace multimediálních prostředků do edukačního procesu, je potřeba nejprve vymezit některé pojmy související s touto problematikou. Pojem multimédia může mít mnoho významů v závislosti na kontextu použití tohoto termínu. Obecně vzato je pod tímto pojmem chápána interpretace jakéhokoliv obsahu za podpory více prostředků užívaných ke komunikaci (Chromý, 2006). Z pohledu výuky by tato definice zahrnovala i klasický výklad doprovázený psaním nebo kreslením na tabuli. Nicméně vzhledem k dostupnosti moderních technologií v dnešní době lze za multimédia považovat takové interpretační prostředky, které poskytují audiovizuální podporu výuky, tedy mluvené či psané slovo, zvuk, fotografie, grafy, animace, videa apod. (Andersen \& Brink, 2002; Mayer, 2009). Z pohledu žáka jsou multimédia takové prostředky, které zapojují současně jejich zrak a sluch. V dnešní technické době může být několik druhů médií spojeno do jednoho zařízení, kterým je nejčastěji počítač nebo tablet ve spojení s prezentačním zařízením (projektor, interaktivní tabule aj.).

Dalším běžně užívaným termínem v oblasti aplikace multimédií do výukového procesu je pojem multimediální vzdělávání, respektive multimediální výuka, který představuje využívání několika komunikačních prostředků za účelem prezentace konkrétního učiva (Chromý, 2006). Žáci se učí a získávají nové informace za přispění verbálního (mluvené nebo tištěné slovo) a vizuálního projevu (ilustrace, fotografie, animace, video). Multimediální instrukce by měla být zpracována takovým způsobem, aby u žáka iniciovala maximální efektivitu osvojování nových poznatků. Zapojení více smyslů vnímání, především zraku a sluchu, je jedním z předpokládaných kroků ke zvýšení efektivity učení, čehož využívá implementace multimédií do vzdělávání (Mayer, 2009). V poslední době je ve školství velice často ve spojitosti s multimediální výukou používán pojem interaktivní. V praxi to znamená, že interaktivní multimédium, např. počítačová prezentace, využívá ke vzájemnému působení a komunikaci ovládání myši, dotyku (touch screen) a jiných nástrojů, které umožňují navigaci v rámci výukového procesu (Chromý, 2006; Evans \& Gibbons, 2007).

Interaktivitou je míněna také určitá kontrola nad tempem a průběhem dalších kroků prezentace (Betrancourt, 2005).

\section{APLIKACE MULTIMÉDIÍ DO VZDĚLÁVACÍHO PROCESU}

V současné době jsme zaplavováni nejmodernějšími technologiemi a je téměř nemožné držet krok se všemi multimediálními trendy. V souvislosti s tím se nabízí otázka, které multimediální prostředky ovlivňují žáky a jejich znalosti nejvíce, a které by současně byly aplikovatelné do každodenní výuky (Berk, 2009). Multimédia mo- 
hou reprezentovat poměrně silný prostředek pro vzdělávání, záleží však na způsobu jejich integrace do výuky a způsobu využití jejich potenciálu. Mayer (2009) vymezuje dva přístupy k aplikaci multimédií do vzdělávacího procesu: „Technology-Centered“, přístup zaměřený na technologie, a „Learner-Centered“, přístup zaměřený na žáka. První z nich, Technology-Centered, souvisí přímo s rozvojem technologií a jejich bezprostřední aplikací do výuky. Tento př́istup využívá špičkových technologií pro vytvoření výukového materiálu, nicméně přitom opomíjí lidský faktor a způsoby učení žáků. Řeší především otázku, jak můžeme technologické možnosti využít při tvorbě instruktážního, respektive výukového materiálu dle Mayera (2009) však přístup není procesem učení prŕliš ovlivněn. Při pohledu do minulosti je patrné, že pouhé zavedení nové technologie do výuky nezaručuje trvalé zlepšení v oblasti vzdělávání (Cuban, 1986). Problémem zde není to, že by moderní informační technologie a jiné vyhledávací a zobrazovací prostředky nemohly být ve škole či mimo ni účinným nástrojem získávání informací a následné práce s nimi. Štech vidí hlavní potíž v tom, že ,z nástroje činíme účel sám o sobě a vytěsňujeme na okraj otázku obsahu a smyslu vzdělávací činnosti“ (2007: s. 331). S tímto názorem se shoduje i Mayer (2009), který kritizuje přístup Technology-Centered za přílišné podřízení se moderním technologiím namísto toho, aby se technologie přizpůsobily potřebám žáků. Východiskem implementace multimédií do výuky by neměla být samotná technologie, ale zájem o rozvoj lidského vědění a poznání. V minulosti byl důraz kladen spíše na zpřístupnění nejnovějších technologií veřejnosti než na jejich pomoc a využití při procesu učení (Cuban, 1986). Oproti tomu přístup Learner-Centered chápe použití multimédií jako prostředek k učení a zefektivnění výuky. Bere v úvahu fungování lidské mysli a pokládá si otázku, jak můžeme aplikovat multimédia do výuky, abychom ji co nejvíce zefektivnili. Důraz je kladen na využívání multimediálních technologií pouze jako pomůcky k rozvoji lidského poznání a schopností žáků (Mayer, 2009). Multimediální prostředky mají doplňovat lidské schopnosti, podporovat činnosti, které nejsou naší silnou stránkou, a zlepšovat a rozvíjet ty oblasti, ve kterých naopak vynikáme.

Z výše uvedeného vyplývá, že pokud má být implementace multimédií do výukového procesu úspěšná, nesmí se výuka podřizovat technologiím, ale naopak musí technologie cíleně sloužit k rozvoji lidského učení a respektovat jeho průběh. Multimediální vzdělávání, resp. výuka probíhá v okamžiku, kdy žáci zaznamenávají informace prezentované dvěma a více různými způsoby, např́íklad vizuálně prezentovaná animace $\mathrm{v}$ kombinaci s verbálně prezentovaným vysvětlujícím komentářem. Účastník takové výuky používá při učení více smyslů a vytváří si komplexnější znalosti, díky kterým je schopen informace lépe přijmout a dlouhodobě uchovat (Clark \& Paivio, 1991). Analogicky, je-li předmětem výuky vysvětlení nějakého principu, kombinací vizuální a verbální prezentace informací se zvyšuje pravděpodobnost pochopení popisovaného principu a vhodnost eventuální aplikace při řešení nastalých situací (Mayer \& Sims, 1994). Mayer a Moreno (2003: s. 44) upozorňují na tři předpoklady, podle kterých funguje lidská mysl při multimediálním vzdělávání: 1) předpoklad dvou informačních kanálı̊; 2) předpoklad omezené kapacity; 3) předpoklad aktivního zpracování informace. To v praxi znamená následující: 1) Pro př́ijem zaznamenané informace využívá člověk dva oddělené informační kanály - sluchový/verbální kanál pro příjem mluvených informací a zrakový/vizuální kanál pro př́ijem informací obrazového charakteru. Vhodně vytvořené multimediální prezentace využívají oba tyto kanály současně, čímž maximalizují efektivitu př́ijmu informací. 2) V aktuálním čase má vizuální i verbální informační kanál pro záznam pouze omezenou kapacitu. $\mathrm{Z}$ tohoto důvodu není př́lišs efektivní použít k vysvětlení určitého principu např. 
animaci doprovázenou výkladovým textem bez mluveného slova kvůli přetížení vizuálního záznamového kanálu (Mayer, 2009). 3) Učení vyžaduje značné kognitivní zpracování v obou informačních kanálech a je aktivním procesem. Zahrnuje sledování prezentovaného materiálu, organizaci přijatých informací do souvislé struktury a integraci prezentovaného materiálu do systému již existujících vědomostí (Mayer \& Moreno, 2003). Model procesu zpracování informací při multimediálním učení znázorňuje obr. 1 (Mayer, 2009), ze kterého je patrné, že žák zapojuje zároveň smyslové vnímání, aktuálně pracující pamět a znalosti uložené v dlouhodobé paměti.

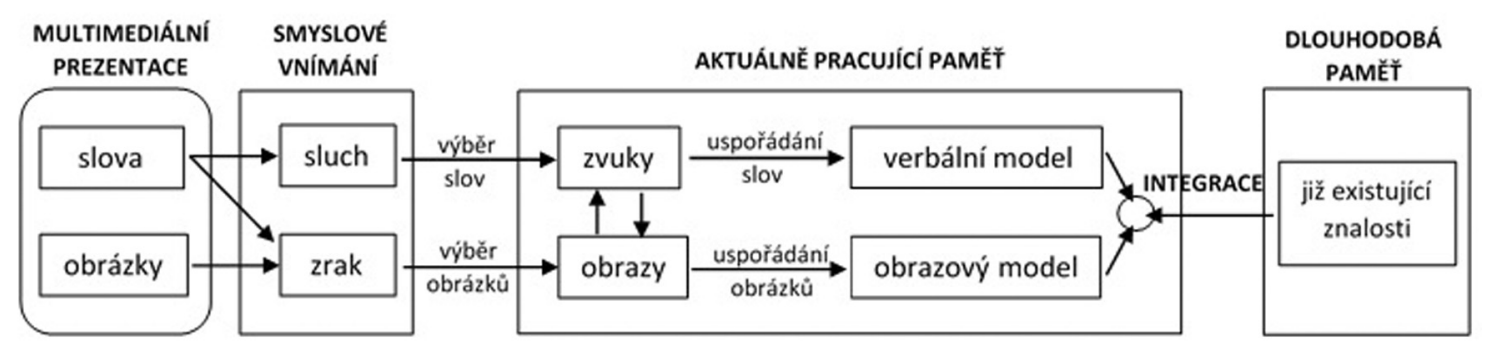

Obr. 1: Model zpracování informací při učení za použití multimédií (Mayer, 2009)

Obr. 1 vyjadřuje kognitivní zpracování informací při multimediálním učení ve směru šipek zleva doprava. Slova a obrázky, které přicházejí z vnějšího zdroje, respektive z multimediální prezentace, jsou zachycovány zrakem a sluchem (smyslové vnímání). Obrazový materiál, včetně tištěného textu, je zaznamenáván zrakem (šipky vedené od slov a od obrázků směrem ke zraku). Následně je veškerý obrazový materiál krátce zpracováván vizuální pamětí. Naopak mluvené slovo zaznamenává sluch (šipka vedená od slov ke sluchu) a zpracovává jej verbální pamět. Pro aktuální práci s přijatými informacemi vybírá žák automaticky pouze pro něj podstatné informace, se kterými později pracuje ( výběr slov“ a „výběr obrázkư"). Vybrané pojmy a informace jsou dále tř́iěny a uspořádány. Žák, respektive jakýkoliv účastník vzdělávacího procesu vytváří souvislé slovní vyjádření na základě předchozích slovních vjemů („uspořádání slov“) a souvislé obrazové představy vycházející z příchozích vizuálních podnětů („uspořádání obrázkư“). Poznatky zjištěné prostřednictvím obou forem aktuálně používané paměti (verbální, vizuální) jsou kombinovány s vědomostmi, kterými disponuje žákova dlouhodobá pamět. Proces integrace (šipka s označením ,integrace“) vyžaduje dočasný přechod a aktivizaci znalostí z dlouhodobé paměti do aktuálně používané paměti. Kapacita dlouhodobé paměti pro ukládání přijatých poznatků je prakticky neomezená, zatímco kapacita paměti umožňující zpracování právě přijatých obrazových a verbálních informací je omezená. Z tohoto důvodu je potřeba v rámci vzdělávacího procesu dbát na nepřetěžování některého z informačních kanálů, což správně vedené multimediální vzdělávání umožňuje (Mayer, 2009).

\section{MULtimÉdia V KONTEXTU HLAVNÍCH TRENDŮ PŘÍRODOVĚDNÉHO VZDĚLÁVÁNÍ}

S ohledem na fakta uvedená v úvodním oddíle můžeme konstatovat, že zdánlivě nové požadavky současného kurikula přrírodovědného vzdělávání vlastně nejsou úplnou novinkou. Dnešní podoba a možnosti společnosti však nabízí odlišné uchopení

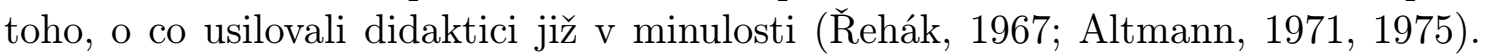


Moderní doba umožňuje učitelům využívat $\mathrm{k}$ dosažení požadovaných cílů nové výukové metody založené na kritickém myšlení, ale také technické prostředky, které jsou nedílnou součástí běžného života nás všech. Výpočetní technika dostupná v 20. a 21. století má potenciál rozvoje lidského poznání takovými způsoby, které nebyly dřive dostupné (Mayer, 2009). Přírodní vědy mají navíc díky svému dynamickému rozvoji veškeré předpoklady pro aplikaci nových výukových metod a prostředků (Joshi, 2011).

Podle Normana (1993) je správná aplikace multimediálních prostředků do výuky jedním z př́kladi̊ toho, co ovlivňuje rozvoj žákovy inteligence. Multimédia jsou již dlouhodobě a rozsáhle aplikována v průmyslových odvětvích, kde je jim přisuzováno zvýšení efektivity a produktivity zaměstnanců (Zoltan \& Chapanis, 1982). Toho je využíváno zejména $\mathrm{v}$ tzv. Computer-Based Training modulech v soukromých sektorech, kde jsou zaměstnanci školeni ohledně organizačních postupů dané korporace. Tento fenomén v současné době vstupuje i do vzdělávacího systému jako vhodný výukový nástroj. Ačkoliv se školské reformy v ČR v posledních dvaceti letech snaží hledat stále nové a efektivnější výukové metody a didaktické prostředky, klasický výklad nelze úplně eliminovat a nahradit. I tato metoda výuky ale může být vedena $\mathrm{v}$ souladu s novodobými trendy. Použití multimédií je jedním z nejdostupnějších řešení, jak aktivovat vnímání žáků zapojením více smyslů a podpořit tzv. činnostní vyučování (Mousavi et al., 1995). Výzkumy dokazují, že lidé si zapamatují $20 \%$ toho, co vidí, 40 \% toho, co slyší a vidí, ale až $75 \%$ toho, co vidí, slyší a zároveň dělají (Lindstrom, 1994). Nejen, že smyslovému vnímání je přisuzována evokace pozitivních postojů k dané problematice, ale rovněž bylo prokázáno, že použití multimédií zvyšuje míru uchování informací a zkracuje dobu učení (Joshi, 2011). Počítačové animace doprovázené vhodným komentářem, popřípadě doplňkovou interaktivní úlohou, mohou například sloužit k vysvětlení principů, které žáci později využijí v rámci výuky vedené badatelským způsobem (Mayer \& Sims, 1994). Výhodou použití multimédií je částečná redukce organizační formy orientované na učitele a otevření výuky směrem $\mathrm{k}$ žákům. Osobnost učitele však zůstává velice důležitá pro správnou interpretaci předávaného učiva.

Multimédia mají své opodstatnění i v souladu se snahou zatraktivnit učivo současným žákům. Prostřednictvím použití multimédií jsou žáci do jisté míry stavěni do podmínek reálného života, jelikož v dnešní době je jejich používání každodenní nutností v jakémkoliv zaměstnání (Joshi, 2011). Jejich zavedení do výuky mưže být jistou motivací pro studium přírodních věd, které jsou mnohdy považovány za abstraktní a obtížné k pochopení (Barak \& Dori, 2005). Výuka tak získává pro mnohé žáky organizovanější podobu a multimédia jim usnadňují pochopení složitých nebo ne př́liš zajímavých témat (Tuovinen, 2000). Názornosti mohou využít i v případech, kdy nemají k dispozici náročná a drahá laboratorní vybavení. Dokážou tak prostřednictvím médií prezentovat např. pokusy a procesy doprovázené bouřlivými a nebezpečnými reakcemi, experimenty dlouhodobého charakteru nebo reakce v tak malých měřítkách, že by pro celou třídu nebyly efektivní. Pomocí statických nebo dynamických multimédií mohou učitelé vizualizovat složité př́rodovědné pojmy, postupy a zvýšit úroveň porozumění a aplikace učiva (Lindstrom, 1994; Mayer, 2009). Pro přírodní vědy je důležitá i možnost multimediálně zprostředkované pokusy kdykoliv opakovat a rozfázovat podle aktuálních potřeb (Pence, 1993).

Vzhledem k soudobému trendu tzv. integračního, respektive multidisciplinárního přístupu k př́rodním vědám (Younès, 2000; Wake, 2008), jsou multimédia ideálním prostředkem pro prezentaci jakéhokoliv učiva. Internet je dnes běžným, a pro současné žáky téměř jediným akceptovatelným informačním zdrojem (Ratchford et al., 
2001). Poskytuje často poměrně komplexní a interdisciplinární informace různého druhu a kvality. Tato komplexnost by měla zůstat zachována i při tvorbě didaktických materiálů podpořených multimédii, například přidáním tabulek, obrázků, grafů, zvukových a obrazových efektů nebo videoklipů. Na druhou stranu materiály obsahující irelevantní zvuky, zajímavý, ale nesouvisející text nebo nepodstatné obrázky, mohou významně redukovat porozumění prezentovanému učivu (Bartsch \& Cobern, 2003). Úlohou učitele je eliminovat tyto rušivé elementy při tvorbě vlastního didaktického materiálu, popřípadě srozumitelně vysvětlit prezentovaný obsah, pokud je k výuce použit cizí didaktický materiál, např. volně stažitelné prezentace, online didaktické materiály, výukové animace. Zároveň je potřeba na tuto skutečnost upozornit žáky a při vyhledávání informací je vést ke kritickému myšlení a ověrování používaných zdrojů.

Aplikace multimédií do výukového procesu je bezpochyby jednou z variant, jak žákům zprostř̌edkovat mnohdy nestravitelné učivo cestou, která je jim v dnešní době blízká. Mnohé studie si multimédií považují zejména kvůli kombinaci psaných a mluvených slov s obrazovým materiálem, statickým i dynamickým, což prokazatelně zvyšuje efektivitu učení (Reimann, 2003; Mayer, 2009). Možnost aplikovat interaktivní prvky do prezentovaného materiálu činí z multimédií mimo jiné vhodný prostředek pro podporu v dnešní době propagovaného činnostního vyučování (Beauchamp \& Kennewell, 2010). Výuka podpořená promyšlenou a přiměřenou aplikací multimediálních prostředků se zdá být jednou z variant, jak vyhovět aktuálním trendům př́rodovědného vzdělávání.

\section{ZÁVĚR}

Aktuální trend českého i evropského vzdělávání nejen v přírodních vědách je poměrně jasně formulován - výuku mají mít ve svých rukou ve velké míre žáci sami a učitelé je mají na cestě za poznáním pouze doprovázet a směrovat (Kotrba \& Lacina, 2007). Volbou vhodných motivačních prvků a aktivizačních metod mají učitelé v žácích probudit zájem o přírodní vědy, které nejsou v současné době př́liš populární pro svou náročnost a odtržení učiva od reality (Víšek \& Kleskeň, 2010). Žáci by měli být vedeni tak, aby sami dokázali vyhledávat informace, ověřovat teoretické poznatky, popřípadě sami dovedli navrhnout metody řešení přírodovědných problémů. Soudobé strategie dosažení požadovaných cílů výuky přírodních věd se vzhledem $\mathrm{k}$ aktuálně dostupným prostředkům pro výuku poměrně liší od historických, nicméně požadavky společnosti v problematice př́rodovědného vzdělávání zůstávají vesměs identické. Již během 20. století se čeští přírodovědci výrazněji za-

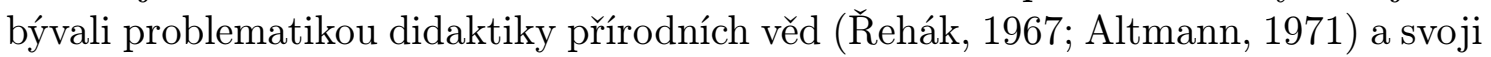
pozornost soustředili na hledání takových výukových postupů, které by žákům přírodní vědy maximálně přiblížily a výuku zefektivnily podobně, jako je tomu dnes.

Za jeden z vhodných prostředků pro přiblížení výuky žákům jsou považována multimédia, respektive vhodná implementace různých typů médií do výuky s ohledem na didaktickou znalost obsahu a potřeby žáků. Vzhledem k aktivaci dvou rozdílných informačních kanálů - sluchového a zrakového - při multimediálním vzdělávání je jejich použití při výuce vysoce efektivní (Lindstrom, 1994). Poměrně rychlý vývoj multimédií umožňuje studentům čím dál tím větší měrou aktivně se zapojit do výuky. S multimediálními technologiemi mohou vytvářet multimediální aplikace jako součást svých výstupů z různých projektů, bádání a jiných $\mathrm{k}$ tomu určených forem výuky. To z žáků činí aktivní účastníky procesu učení, kteří jsou vedeni k samostat- 
nému rozhodování o obsahu jejich výstupů a kriticky hodnotí relevanci informací, se kterými pracují. Výhodou multimediálních prostředků navíc je, že učiteli dovolují použivat ve třídě rozdílné výukové styly a způsoby sdělování odborného obsahu. Tím jsou výukou osloveni žáci poměrně širokého spektra s rozdílnými potřebami. Vzhledem k tomu, že učitelé mohou využít všech obohacujících prvků, které multimédia zprostředkovávají, uplatňují ve výuce větší škálu svých nápadů. Žáci dané učivo vidí, slyší a představují si mnohem realističtěji, což zvyšuje úroveň aplikace a pochopení učiva. Důležitou úlohu hrají multimédia rovněž v otázce motivace, které současní žáci potřebují relativně velkou dávku. Za přispění multimediálních prostředků může učitel pozdvihnout zdánlivě nezajímavé téma na úroveň akceptovatelnou žáky. Kombinace multimediálních prezentací, činnostního vyučování a tradičních výukových technik může být také hodnotnou podporou např. badatelsky orientované výuky (Pence, 1993; Younès, 2000; Papáček, 2010) a činnostního vyučování jako celku.

\section{LITERATURA}

Altmann, A. (1971). Didaktické zásady ve výuce biologii (Kapitola z didaktiky biologie). Praha: SPN.

Altmann, A. (1975). Metody a zásady ve výuce biologii. Praha: SPN.

Andersen, B. B. \& Brink, K. (2002). Multimedie in education (Specialised training course). Moskva: Unesco Institute for Information Technologies in Education.

Barak, M. \& Dori, Y. J. (2005). Enhancing undergraduate students' chemistry understanding through project-based learning in an IT environment. Science Education, 89(1), 117-139.

Bartsch, R. A. \& Cobern, K. M. (2003). Effectiveness of PowerPoint presentations in lectures. Computers \& Education, 41, 77-86.

Beauchamp, G. \& Kennewell, S. (2010). Interactivity in the classroom and its impact on learning. Computers \& Education, 54, 759-766.

Berk, R. A. (2009). Multimedia teaching with video clips: TV, movies, YouTube, and $\mathrm{mtv} \mathrm{U}$ in the college classroom. International Journal of Technology in Teaching and Learning, 5(1), 1-21.

Betrancourt, M. (2005). The animation and interactivity principles in multimedia learning. In R. E. Mayer (Ed.), The Cambridge handbook of multimedia learning (287-296). New York: US: Cambridge University Press.

Chromý, J. (2006). Analýza výkladu pojmů média a multimédia. Technology of Education, 14(3), 5-8.

Clark, J. M. \& Paivio, A. (1991). Dual coding theory and education. Educational Psychology Review, 3(3), 149-210.

Cuban, L. (1986). Teachers and machines: The classroom use of technology since 1920. New York: Teachers College Press.

Evans, Ch. \& Gibbons, N. J. (2007). The interactivity effect in multimedia learning. Computers \& Education, 49, 1147-1 160.

Held, L. (2011). Konfontácia koncepcií prírodovedného vzdelavania v Európe. Scientia in Educatione, 2(1), 69-80. 
Joshi, A. (2011). Innovative teaching: Using multimedia in a problem-based learning environment. Current World Environment: An International Reasarch Journal of Environmental Science, 6(1), 183-186.

Komenský, J. A. (1958). Velká didaktika. Vybrané spisy Jana Amose Komenského. Praha: SPN.

Kotrba, T. \& Lacina, L. (2007). Praktické využití aktivizačních metod ve výuce. Brno: Barrister a Principal.

Lindstrom, R. (1994). Create dynamic presentations that inspire. In R. Lindstrom (Ed.), The business week guide to multimedia presentations: create dynamic presentations that inspire. New York: Mcgraw-Hill Osborne Media.

Mayer, R. (2009). Multimedia learning. New York: Cambridge University Press.

Mayer, R. E. \& Moreno, R. (2003). Nine ways to reduce cognitive load in multimedia learning. Educational Psychologisst, 38(1), 43-52.

Mayer, R. E. \& Sims, V. K. (1994). For whom is a picture worth a thousand words? Extensions of a dual-coding theory of multimedia learning. Journal of Educational Psychology, 86(3), 389-401.

Mousavi, S. Y., Low, R., \& Sweller, J. (1995). Reducing cognitive load by mixing auditory and visual presentation modes. Journal of Educational Psychology, 87(2), $319-334$.

Norman, D. A. (1993). Things that make us smart: defending human attributes in the age of the machine. New York: Addison-Wesley Publishing Company.

Papáček, M. (2010). Badatelsky orientované př́rodovědné vzdělávání - cesta pro vzdělávání generací Y, Z a alfa? Scientia in Educatione, 1(1), 33-49.

Pavelková, I., Škaloudová, A. \& Hrabal, V. (2010). Analýza vyučovacích předmětů na základě výpovědí žáků. Pedagogika, 60(1), 38-61.

Pence, H. E. (1993). Combining cooperative learning and multimedia in general chemistry. Education, 113(3), 375-380.

Ratchford, B. T., Talukdar, D. \& Lee, M. S. (2001). A model of consumer choice of the Internet as an information source. International Journal of Electronic Commerce, 5(3), $7-22$.

Reimann, P. (2003). Multimedia learning: beyond modality. Learning and Instruction, $13,245-252$.

Řehák, B. (1967). Vyučování biologii (na základní devítileté škole a střední všeobecně vzdělávaci škole). Praha: SPN.

Santiago, P., Gilmore, A., Nusche, D. \& Sammons, P. (nedatováno). Zprávy OECD o hodnocení vzděláváni - Česká republika 2012. Dostupné z ČS̆I - Česká školní inspekce: http://www.csicr.cz/getattachment/a6311b50-169c-4e5e-9d92-a6f70aafe0f1

Schulman, L. S. (1987). Knowledge and teaching: Foundations of the new reform. Harvard Educational Review, 57, 1-22.

Škoda, J. \& Doulík, P. (2009). Vývoj paradigmat přírodovědného vzdělávání. Pedagogická orientace, 19(3), 24-43.

Štech, S. (2007). Profesionalita učitele v neoliberální době (Esej o paradoxní situaci učitelství). Pedagogika, 57(4), 326-337. 
TIMSS International Study Center. (1996). Highlights of results from TIMSS. Boston: Boston College.

Tuovinen, J. E. (2000). Multimedia distance education interactions. Education Media Internationoal, 37(1), 16-24.

Veselský, M. (2010). Motivácia žiakov učit sa: Teória a prax. Bratislava: Univerzita Komenského Bratislava.

Víšek, T. \& Kleskeň, B. (2010). Klesající výsledky českého a základního školství: fakta a řěseni. Praha: McKinsey \& Company.

VÚP. (2011). Př́rodovědná gramotnost ve výuce. Praha: NÚV.

Wake, M. H. (2008). Integrative biology: Science for the 21st century. BioScience, 58(4), $349-353$.

White Wolf Consulting. (2009). Důvod nezájmu žáků o př́rodovědné a technické obory. Individuální projekt národní Podpora technických a př́rodovědných oborů 2010, Ministerstvo školství, mládeže a tělovýchovy. Dostupné z http://www.generacey.cz/duvody-nezajmu-zaku-o-prirodovedne-a-technicke-obory Younès, T. (2000). Biological education: Challenges of the 21st century. Biology International, 39, 8-13.

Zoltan, E. \& Chapanis, A. (1982). What do professional persons think about computers. Computers in Human Behavior, 9, 411-426.

TerezA Odcházelová, tereza.odchazelova@pedf.cuni.cz Univerzita Karlova v Praze, Pedagogická fakulta

Katedra biologie a environmentálních studií

Magdalény Rettigové 4, 11639 Praha 1, Česká republika 